\title{
PENGEMBANGAN BUKU AJAR BIOLOGI BERBASIS PROJECT BASED LEARNING UNTUK MENINGKATKAN KREATIVITAS SISWA SMA NEGERI 1 PENENGAHAN LAMPUNG SELATAN
}

\author{
Asep Nedyana \\ SMA Negeri 1 Penengahan \\ E-mail: anedyana@gmail.com
}

\begin{abstract}
The aims of this research is to improve textbook basically project based learning to increasing student creativity that expect that become lesson object and lesson source of biology supporting, understand quality of textbook based on qualification material, presentation, language, and understanding, as soon as understanding respond of students concerning textbook, cognitive result, and student creativity levels. This research using development research with development model 4 stages and have the purpose of research and development from Borg \& Gall. Data can we gets from test result cognitive and creativity assessment such as tabulation data with doing validation, reliability, and homogeneity with assistance computer program SPSS 16.0, so that knowing there is differences or nothing level of study result pre-test and post-test of class groups on using textbook with class group that not using textbook by examination t-test. The development of textbook has validation by expert and employing is very good to use. There is differences in levels and the result of the study and creativity student between the way of treating with class control.
\end{abstract}

Kata kunci: buku ajar, kreativitas, project based learning

Pembelajaran pada kurikulum 2013 dilaksanakan berbasis aktivitas yang memberikan ruang yang cukup bagi peserta didik untuk mengembangkan kreativitas, prakarsa, dan kemandirian yang sesuai dengan potensi, bakat, minat, dan perkembangan fisik serta psikologi peserta didik (Kemendikbud, 2016). Dalam proses pembelajaran diperlukan sumber belajar berupa bahan ajar yang salah satunya adalah buku ajar. Sumber belajar merupakan komponen penting dalam belajar. Menurut Hamalik (2009: 27) belajar adalah "modifikasi atau memperteguh kelakuan melalui pengalaman (learning is defined as the modification or strengthening of behavior through expriencing)". Sedangkan menurut Karwono (2007: 1) dalam proses belajar "komponen sumber belajar itu mungkin dimanfaatkan secara tunggal atau secara kombinasi, baik sumber belajar yang direncanakan maupun sumber belajar yang dimanfaatkan". Selanjutnya Prastowo (2015: 21) mengatakan, sumber belajar adalah "segala sesuatu (bisa berupa benda, data, fakta, ide, orang, dan lain sebagainya) yang bisa menimbulkan proses belajar".

Bahan ajar, terdiri atas dua kata yaitu mengajar dan material atau bahan. Menurut Daryanto dan Dwicahyono (2014: 171) 'bahan Ajar merupakan informasi, alat dan teks yang diperlukan guru untuk perencanaan dan penelaahan implementasi pembelajaran". Buku ajar merupakan bahan ajar dan sumber belajar yang mudah ditemukan dan digunakan. Setiap toko buku memiliki dan menjual buku ajar dengan harga yang terjangkau. Dalam penggunaan juga sangat mudah, peserta didik cukup 
membaca dan memahami materi yang dituangkan dalam buku tersebut, tidak perlu keterampilan khusus lain yang diperlukan untuk menggunakan buku ajar. Karena itulah bahan cetak ini banyak digunakan (Prastowo: 2012).

Berhasil tidaknya pembelajaran bergantung apa yang diberikan dan diajarkan oleh guru. Selama ini pembelajaran cenderung berpusat pada guru dan siswa hanya sebagai objek belajar. Melalui kurikulum 2013 diharapkan terjadinya perubahan paradigma pembelajaran yang inovatif dan berpusat pada siswa. Salah satu terobosannya adalah pembelajaran yang dilakukan melalui model pembelajaran yang memberi ruang bagi siswa untuk bebas mengemukakan pendapat dan mendalami materi pembelajaran sesuai dengan tujuan yang sudah dicanangkan. Model pembelajaran adalah suatu perencanaan atau suatu pola yang digunakan sebagai pedoman dalam merencanakan pembelajaran di kelas atau pembelajaran dalam tutorial (Trianto, 2011:51).

Proyek adalah tugas-tugas belajar (learning tasks) yang meliputi kegiatan perancangan, pelaksanaan, dan pelaporan secara tertulis maupun lisan dalam waktu tertentu. Menurut Warsono dan Hariyanto (2014: 152) pembelajaran berbasis proyek merupakan penerapan dari pembelajaran aktif teori konstruktivisme dari Piaget serta teori konstruksionisme dari murid Piaget, Seymour Paret.

Senada dengan Astuti (2015: 3) bahwa pembelajaran di luar kelas berbasis proyek yang telah dikembangkan dapat meningkatkan keterampilan berpikir kreatif siswa dalam membuat proyek untuk menangani limbah yang ada di lingkungan sekolah.
Pembelajaran berbasis proyek merupakan model pembelajaran yang memberikan kesempatan kepada guru untuk mengelola pembelajaran di kelas dengan melibatkan kerja proyek (Hardini dan Puspitasari, 2012: 127). Kreativitas pada anak merupakan dasar penting bagi kemampuannya menghadapi perubahan zaman dimasa depan. Menurut Munandar (2014 : 78) sukar untuk menentukan satu definisi yang operasional dari kreativitas, karena kreativitas merupakan konsep yang majemuk dan multi dimensional.

Kreativitas juga diartikan sebagai kemampuan seseorang untuk melahirkan sesuatu yang baru baik berupa gagasan maupun karya nyata, yang relatif berbeda dengan apa yang telah ada sebelumnya (Supriyadi, 1994 : 7). Dengan demikian kreativitas merupakan segala bentuk daya dan usaha serta produk yang dihasilkan yang merupakan hasil dari belajar.

Kurangnya sumber belajar dalam materi limbah dan daur ulang limbah, diikuti oleh rendahnya penguasaan kompetensi siswa, maka dipandang perlu segera meneliti dan mengembangkan produk buku ajar yang berkaitan dengan materi limbah dan daur ulang limbah.

Berdasarkan latar belakang di atas, maka penelitian dan pengembangan ini bertujuan untuk:

1. Mengembangkan buku ajar biologi berbasis project base learning $(\mathrm{Pj} \mathrm{BL})$ sebagai sumber belajar alternatif biologi untuk siswa kelas X SMA Negeri 1

2. Penengahan yang memenuhi kualifikasi materi, pedagogi, dan keterbacaan,

3. Mengetahui respon peserta didik terhadap buku ajar biologi berbasis project based learning (PjBL). 
4. Mengetahui tingkat kreativitas belajar siswa dengan penggunaan buku ajar biologi berbasis project base learning (PjBL).

\section{METODE}

Penelitian ini merupakan penelitian pengembangan, dengan model pengembangan 4 tahap yang mengacu pada Research and Development dari Borg \& Gall. Tahapan tersebut adalah: studi pendahuluan, perencanaan program, pengembangan program, dan validasi dan revisi program. Sesuai dengan pengertian penelitian yang mengacu pada Research and Development dari Borg \& Gall diatas yang meliputi empat tahapan, yaitu: studi pendahuluan, perencanaan program, pengembangan program, dan validasi dan revisi program.

Desain uji coba produk yang dilakukan meliputi uji ahli, uji pengguna, dan uji peserta didik. Berdasarkan hasil uji produk tersebut dilakukan revisi terhadap perangkat buku ajar yang dikembangkan berupa keterbacaan teks dan ketercapaian konsep. Subjek Uji Coba Peserta didik SMA Negeri 1 Penengahan kelas $\mathrm{X}$ IPA semester genap. Data yang diperoleh dari penelitian ini merupakan data primer. Data ini merupakan data yang berkaitan dengan penilaian dan tanggapan dari ahli, guru, dan respon peserta didik tentang bahan ajar yang dikembangkan serta uji kreativitas siswa. Instrumen yang digunakan dalam penelitian ini ada tiga jenis, yaitu tes uraian terbuka, rubrik penilaian kreativitas pada tahap perencanaan, dan rubrik penilaian kreativitas hasil proyek daur ulang limbah. Tes uraian terbuka dalam penelitian ini digunakan untuk mengukur kemampuan berpikir kreatif siswa berdasarkan kemampuan berpikir kreatif menurut Guilford yang meliputi kelancaran (fluency), keluwesan (flexibility), keaslian (originality), perincian (elaboration), dan perumusan kembali/redefinisi (redefinition) (Supriadi, 1994 dalam Talajan, 2012; Munandar, 2014; Getzels, 2010 dalam Talajan, 2012).

Penilaian proyek siswa adalah penilaian terhadap suatu tugas yang harus diselesaikan dalam periode atau waktu tertentu. Instrumen penilaian kreativitas proyek siswa dibuat berdasarkan ciri individu kreatif dan ciri produk kreatif menurut Besemer dan Treffinger (dalam Talajan, 2012). Penilaian kreativitas proyek siswa dilakukan pada beberapa tahapan, yaitu tahap perencanaan dan tahap penilaian hasil proyek daur ulang limbah.

Langkah- langkah

pengembangan instrumen kemampuan berpikir kreatif menggunakan tes uraian terbuka, rubrik penilaian kreativitas pada tahap perencanaan, dan rubrik penilaian kreativitas hasil proyek daur ulang limbah adalah:

- Melakukan judgement instrumen kepada dosen ahli.

- Merevisi soal tes uraian terbuka, rubrik penilaian kreativitas pada tahap

perencanaan, dan rubrik penilaian kreativitas hasil proyek daur ulang limbah berdasarkan judgement instrumen.

- Melakukan uji coba instrumen tes uraian terbuka kepada kelas bukan penelitian.

- Melakukan analisis butir soal tes uraian terbuka meliputi validitas, reliabilitas, daya pembeda, dan tingkat kesukaran.

- Merevisi soal-soal yang perlu diperbaiki pada tes uraian terbuka.

Setelah merevisi soal-soal tes uraian terbuka, peneliti akan melakukan penelitian melalui pembelajaran materi limbah dan daur 
ulang limbah di kelas X IPA SMA Negeri 1 Penengahan.

\section{HASIL}

Tabel 1. Hasil Penilaian Validator Ahli Terhadap Buku Ajar yang Dikembangkan

\begin{tabular}{c|l|c}
\hline No. & \multicolumn{1}{|c|}{ Penilai } & Katrgori* $^{*}$ \\
\hline 1 & Ahli Materi: Dr. Agus Sutanto, M.Si. & Sangat Baik (100\%) \\
\hline 1 & $\begin{array}{l}\text { Ahli Pembelajaran: Dr. Muhfahroyin, } \\
\text { M.T.A. }\end{array}$ & Sangat Baik (88)\% \\
\hline 3 & $\begin{array}{l}\text { Guru Biologi: Ana Triana Maiyah, } \\
\text { S.Pd.,M.Si }\end{array}$ & Sangat Baik (99\%) \\
\hline 4 & Ahli Bahasa: Dra. Non Reni & Sangat baik (98\%) \\
\hline \multicolumn{1}{|l}{ Rata-rata } & Sangat Baik (96,25) \\
\hline
\end{tabular}

(Sumber: data hasil penelitian validasi ahli yang sudah diolah)

Tabel 2. Hasil Uji Keterbacaan Siswa Terhadap Buku Ajar yang dikembangkan.

\begin{tabular}{|l|l|c|l|}
\hline No. & Krite ria & $\begin{array}{l}\text { Rata-rata persentase } \\
(\boldsymbol{\%})\end{array}$ & Kategori \\
\hline 1 & Tampilan fisik buku ajar & $91(\%)$ & Sangat baik \\
\hline 2 & Materi / isi & $88,5(\%)$ & Sangat baik \\
\hline 3 & Bahasa & $91(\%)$ & Sangat baik \\
\hline \multicolumn{2}{|c|}{$\begin{array}{c}\text { Rata-rata keterbacaan siswa } \\
\text { terhadap buku ajar }\end{array}$} & $90,17(\%)$ & Sangat baik \\
\hline
\end{tabular}

Tabe13. Rata-rata masing-masing kelompok

\begin{tabular}{|l|l|l|l|c|c|l|l|}
\hline $\mathrm{A}$ & Kelas & $\mathrm{N}$ & Mean & $\mathrm{SD}^{2}$ & $\mathrm{t}_{\text {hitung }}$ & $\mathrm{t}_{\text {tabel }}$ & Sig. \\
\hline \multirow{2}{*}{0,05} & Perlakuan & 30 & 78,4000 & 7,66474 & 5,291 & 2,00 & 0,000 \\
\cline { 2 - 5 } & Kontrol & 30 & 69,5500 & 5,01781 & & & \\
\hline
\end{tabular}

Tabel 4. Output SPSS Hasil Analisis Uji-t Kreativitas Belajar

\begin{tabular}{|l|l|l|l|c|c|l|l|}
\hline $\mathrm{A}$ & Kelas & $\mathrm{N}$ & Mean & $\mathrm{SD}^{2}$ & $\mathrm{t}_{\text {hitung }}$ & $\mathrm{t}_{\text {tabel }}$ & Sig. \\
\hline \multirow{2}{*}{0,05} & Perlakuan & 30 & 78,4000 & 7,66474 & 5,291 & 2,00 & 0,000 \\
\cline { 2 - 6 } & Kontrol & 30 & 69,5500 & 5,01781 & & & \\
\hline
\end{tabular}

Hasil penelitian dan pengembangan ini meliputi penyajian data uji coba, analisis data, dan revisi produk yang dikembangkan yang diperoleh empat pokok data hasil. Pada bagian pertama data hasil uji coba identifikasi penilaian buku ajar oleh validator ahli (guru biologi, ahli materi, ahli pembelajaran, dan ahli bahasa). Pada penyajian data uji coba kedua mendeskripsikan hasil uji keterbacaan buku ajar oleh 10 siswa. Bagian ketiga penyajian data uji coba penerapan buku ajar dan kreativitas siswa berdasarkan tes uraian terbuka. Bagian keempat berupa data kreativitas proyek hasil perencanaan dan produk di kelas perlakuan dan kelas non perlakuan (kontrol).

Pada penelitian dan pengembangan ini disusun sebuah produk berupa buku ajar Limbah dan Daur Ulang Limbah. Sebelum melakukan uji coba produk, instrumen terlebih dahulu dilakukan validasi oleh dosen ahli materi dan ahli 
pembelajaran dan untuk hal ini penulis memohon kesediaan Bapak Dr. Agus Susanto, M.Si., Bapak Dr. Muhfahroyin, M.T.A., dan satu orang guru biologi Ibu Ana Triana Maiyah, S.Pd., M.Si., serta satu orang ahli bahasa Ibu Dra. Non Reni (data terlampir). Selanjutnya hasil validasi instrumen dijadikan dasar melakukan revisi yang menyangkut isi instrumen, berupa; tata tulis, penggunaan tanda baca, dan penulisan bahasa asing.

Setelah melakukan tahapan pengidentifikasian, perancangan, dan pengembangan buku ajar, dilakukan penilaian validator yaitu 1 orang guru biologi yaitu Ibu Ana Triana Maiyah, S.Pd., M.Si., 1 orang dosen ahli materi Bapak Dr. Agus Susanto, M.Si., 1 orang dosen ahli pembelajaran yang berkompeten dibidang pembelajaran biologi Bapak Dr. Muhfahroyin, M.T.A., dan 1 orang ahli bahasa Ibu Dra. Non Reni. Penilaian yang dilakukan oleh validator meliputi aspek struktur/format, materi/isi, dan bahasa. Lembar hasil validasi oleh guru biologi, ahli materi, ahli pembelajaran dan ahli bahasa. Dari lembar validasi yang dinilai oleh validator diperoleh hasil penilaian dari validasi yang terlihat pada tabel 1.

Berdasarkan hasil identifikasi penilaian buku ajar oleh validator ahli seperti pada tabel 1, guru biologi memberikan skor $99 \%$, seorang ahli materi memberikan skor $100 \%$, seorang ahli pembelajaran memberikan skor $80 \%$, dan seorang ahli bahasa memberikan skor $98 \%$. Berdasarkan acuan tingkat kelayakan buku ajar menurut ahli dan pengguna maka keempat faktor tersebut tergolong sangat baik sehingga sangat layak untuk digunakan sebagai sumber bacaan dilihat dari sisi materi dan pembelajaran.

Penilaian masing-masing ahli sedikit berbeda, tetapi hasil penilaian tersebut menunjukkan kriteria kelayakan untuk digunakan. Berikut ini disajikan data hasil penilaian oleh dosen ahli materi. Dari hasil perhitungan diketahui persentase nilai kelayakan dari hasil perhitungan data uji coba ahli materi buku ajar sebesar $100 \%$. Berikutnya penilaian yang dilakukan oleh ahli pembelajaran yang dilakukan oleh dosen yang berkompeten dalam pembelajaran biologi.

Dari data diperoleh nilai presentase kelayakan buku ajar menurut ahli pembelajaran sebesar $88 \%$ yang menunjukkan kriteria sangat layak untuk digunakan dalam pembelajaran biologi di SMA kelas X. Walaupun terdapat saran dan revisi pada sumber blog dan kontekstual berbasis lokal pada buku ajar tersebut. Masukan dari ahli materi dan ahli pembelajaran sangat bermanfaat untuk merevisi buku ajar dan kelanjutan produk dan uji coba pada siswa kelas X. Penilaian yang dilakukan oleh guru biologi sebagai pengguna terhadap buku ajar.

Dari data hasil penelitian diperoleh nilai persentase kelayakan buku ajar sebesar $98,67 \%$ yang berarti menunjukkan menurut guru biologi buku ajar sangat layak untuk dipergunakan dalam pembelajaran biologi di SMA kelas X.

Berdasarkan hasil uji respon peserta didik tingkat keterbacaan yang dilakukan pada 10 peserta didik terhadap buku ajar yang dikembangkan, maka diperoleh hasil uji respon peserta didik tingkat keterbacaan termasuk dalam kategori sangat baik atau sangat layak rata-rata 90,17\%. Dari hasil validasi menunjukkan bahwa nilai rata-rata penilaian tiap komponen buku ajar yang dikembangkan termasuk dalam kategori sangat baik atau sangat layak. Kesimpulan dapat diambil 
bahwa seluruh naskah wacana buku ajar yang dikembangkan tersebut telah memenuhi syarat dan layak dipergunakan oleh siswa SMA kelas X semester genap dalam pembelajaran biologi di kelas sesuai kriteria. Data uji coba terhadap penggunaan Buku Ajar Limbah dan Daur Ulang Limbah pada peserta didik untuk melihat adanya peningkatan kreativitas melalui tes uraian terbuka dilakukan menggunakan rubrik penilaian tes uraian untuk mengidentifikasi dan memperoleh gambaran kemampuan berpikir kreatif siswa sebagai berikut:

Dari skor siswa yang diperoleh pada masing-masing pertanyaan yang mewakili kemampuan berpikir kreatif dijumlahkan kemudian dihitung persentase nilai kemampuan berpikir kreatif pada setiap kemampuan. Dapat disimpulkan kemampuan berpikir kreatif siswa yang menggunakan buku ajar sebesar $83,498 \%$ yang berarti kemampuan berpikir kreatif siswa sangat tinggi. Sedangkan kemampuan berpikir kreatif siswa di kelas X IPA 2 atau kelas kontrol yang tidak menggunakan buku ajar adalah 57,51\%. Kemampuan berpikir kreatif siswa sedang. Dari penelitian diperoleh nilai prosentase kemampuan berpikir kreatif siswa adalah berbeda antara kelas perlakuan dengan kelas kontrol.

Tingkat kemampuan berpikir kreatif siswa kelas $\mathrm{X}$ IPA1 yang menggunakan buku ajar sebesar $81,17 \%$ lebih tinggi dibandingkan tingkat kemampuan berpikir kreatif siswa kelas kontrol yang tidak menggunakan buku ajar yaitu 71,50\%. Hal ini menunjukkan bahwa buku ajar yang dikembangkan berbasis Project Based Learning dapat meningkatkan kreativitas siswa lebih tinggi dibandingkan dengan tidak menggunakan buku ajar.

Dari masing-masing jawaban soal yang didapat siswa, skor yang diperoleh menggambarkan tingkatan kemampuan berpikir siswa, yaitu berada dalam tingkat kemampuan berpikir kreatif baik karena berada direntang 14 sampai 18 . Jadi semua siswa di kelas $X$ IPA 1 yang menggunakan Buku Ajar Limbah dan Daur Ulang Limbah sebagai kelas perlakuan memiliki kemampuan berpikir kreatif baik, sedangkan ratarata siswa kelas kontrol yang tidak menggunakan Buku Ajar Limbah dan Daur Ulang Limbah memiliki kemampuan berpikir kreatif sedang.

Data penilaian kreativitas proyek daur ulang siswa terdiri dari dua tahapan, yaitu tahapan penilaian kreativitas pada tahap perencanaan proyek dan tahapan penilaian produk hasil proyek daur ulang limbah. Diperoleh prosentase nilai kreativitas pada tahap perencanaan proyek dan produk daur ulang limbah di kelas $\mathrm{X}$ IPA1 yang menggunakan Buku Ajar menjadi meningkat dibandingkan dengan kelompok kelas X IPA2 yang tidak menggunakan Buku Ajar.

Dari kedua kelas perlakuan dan kelas kontrol, prosentase nilai kreativitas tahap perencanaan dan kreativitas produk dauar ulang nampak berbeda. Untuk kelas perlakuan ratarata prosentase nilai kreativitas tahap perencanaan yaitu $77 \%$; nilai kreativitas produk daur ulang yaitu $80 \%$ dengan rata-rata nilai kreativitas $79 \%$. Prosentase nilai kreativitas siswa kelas perlakuan artinya meningkatkan kreativitas tinggi. Sedangkan pada kelas kontrol prosentase nilai kreativitas tahap perencanaan yaitu 66\%; nilai kreativitas produk daur ulang yaitu $73 \%$ dengan rata-rata $70 \%$. Meskipun kelas kontrol mengalami peningkatan kreativitas tetapi jauh lebih rendah dibandingkan dengan kelas perlakuan. 


\section{PEMBAHASAN}

Berdasarkan penilaian validasi oleh ahli materi kelayakan Buku Ajar Limbah dan Daur Ulang Limbah mendapatkan skor 50 poin dengan prosentase kelayakan mencapai $100 \%$ yang artinya memenuhi kriteria sangat layak untuk digunakan pada uji coba produk dalam pembelajaran biologi SMA kelas X.

Buku Ajar yang berbasis Project Based Learning pada materi limbah dan daur ulang limbah merupakan amanat dari kurikulum 2013 hasil revisi tahun 2016 yang merupakan bagian dari proses pembelajaran dengan pendekatan scientific. Limbah merupakan masalah lingkungan terkini dan sangat mengkhawatirkan merusak lingkungan apabila tidak dikelola secara arif dan bijaksana, salah satunya melalui daur ulang.

Berdasarkan hasil penilaian validasi ahli materi produk Buku Ajar sangat layak. Produk Buku Ajar yang dikembangkan merupakan alternatif sumber belajar dan bahan ajar yang dapat dijadikan pelengkap referensi khususnya tentang limbah dan daur ulang limbah bagi siswa kelas $\mathrm{X}$ dalam pembelajaran biologi. Dengan Buku Ajar terbukti dapat meningkatkan kreativitas dan motivasi belajar siswa. Penyajian yang menarik disertai ilustrasi gambar berwarna mendorong siswa untuk belajar penuh semangat, efektif, dan mandiri.

Berdasarkan penilaian validasi ahli pembelajaran terhadap produk Buku Ajar yang dikembangkan memperoleh 44 poin dengan prosentase kelayakan Buku Ajar sebesar 88,00\%, artinya produk Buku Ajar mendapat kategori sangat layak untuk dipergunakan dan diujicobakan dalam proses pembelajaran biologi di kelas X.

Berdasarkan penilaian validasi oleh Guru Biologi terhadap kelayakan
Buku Ajar diperoleh hasil 74 poin dari skor maksimal 75. Diperoleh prosentase penilaian sebesar $98 \%$. Besarnya prosentase untuk penilaian kelayakan Buku Ajar oleh guru biologi berarti Buku Ajar yang dikembangkan sangat layak sehingga tidak perlu revisi dan dapat dipergunakan melalui uji coba pembelajaran biologi pada materi Limbah dan Daur Ulang Limbah di kelas X SMA.

Berdasarkan penilaian ahli bahasa diperoleh skor 49 poin dari 50 poin maksimal. Maka prosentase kelayakan adalah sebesar $98 \%$. Komponen struktur/format 19 poin dari 20 poin maksimal, sedangkan komponen bahasa diperoleh 20 poin maksimal. Besarnya prosentase kelayakan Buku Ajar sebesar 98\% termasuk kategori sangat layak dan tidak perlu revisi dan dapat digunakan dalam uji coba pembelajaran Biologi pada materi Limbah dan Daur Ulang Limbah.

Uji coba penggunaan Buku Ajar dilaksanakan pada dua kelompok kelas, yaitu kelas X IPA 1 sebagai kelas perlakuan yang menggunakan Buku Ajar dan kelas X IPA 2 tidak menggunakan Buku Ajar sebagai kelas kontrol. Kelas X IPA 1 sebagai kelas perlakuan tahap awal siswa dibagi ke dalam enam kelompok yang terdiri dari 5 orang, yang setiap kelompok diberikan Buku Ajar. Berdasarkan hasil uji analisis data sebagai berikut:

Dalam penelitian ini digunakan instrument validitas isi buku ajar berupa soal tes uraian. Dari lima soal yang divalidasi semuanya diperoleh soal yang valid. Kelima soal uraian tersebut digunakan untuk pengambilan nilai kognitif sekaligus instrument kreativitas peserta didik melalui pretes dan postes. Validasi dilakukan kepada peserta didik yang telah menerima penyajian materi Limbah dan Daur Ulang Limbah yaitu kelas X IPA. 
Berdasarkan hasil validasi, soal nomor 1 sampai dengan nomor 5 diperoleh nilai $t_{\text {hit }}>t_{\text {tabel, }}$ artinya seluruh soal tersebut valid dan dapat digunakan untuk

mengukur seluruh indikator yang terdapat pada kisi-kisi soal.

Uji Normalitas data diambil dari kelas perlakuan untuk mengetahui apakah data yang diperoleh berdistribusi nomal atau tidak. Suatu distribusi dikatakan normal jika taraf signifikansinya lebih besar dari 0,05 sedangkan jika taraf signifikansinya kurang dari 0,05 maka distribusi dikatakan tidak normal. Uji normalitas data dilakukan berupa uji normalitas hasil postes yang dihitung menggunakan SPSS 16.0 melalui uji Kolmogorov-Smirnov.

Uji homogenitas data dilakukan untuk meyakinkan bahwa data yang diperoleh dari populasi yang tidak jauh berbeda keragamannya atau variannya. Uji homogenitas ini diambil dari kelas perlakuan dan kelas kontrol. Perhitungan uji homogenitas menggunakan software SPSS adalah dengan Uji Levene Statistics. Jika nilai Levene Statistics > 0,05 maka dapat dikatakan variasi data adalah homogen.

Karena Asimp Sig $=0,386>$ 0,05 maka data homogen. Setelah data normal dan homogeny maka dilanjutkan uji-t untuk mengetahui perbedaan rata-rata hasil belajar pada kelas perlakuan yang menggunakan buku ajar dan kelas kontrol yang tidak menggunakan buku ajar.

Hasil analisa pengujian terhadap capaian hasil post-test dilakukan dengan membandingkan hasil belajar biologi di kelas perlakuan yang pembelajarannya menggunakan buku ajar dengan kelas kontrol yang tidak menggunakan buku ajar. Hasil belajar yang dibandingkan merupakan skor perolehan siswa berdasarkan selisish dari nilai pre-test dengan nilai post-test. Pengujian dilakukan kepada kelompok subjek penelitian yang setara atau homogen.

Dari hasil pengujian rata-rata kelas perlakuan dan kelas kontrol seperti pada Tabel 2 terlihat jumlah data adalah sama masing-masing kelas ada 30 siswa. Rata-rata (mean) pada kelompok kelas perlakuan diperoleh 81,17 sedangkan kelompok kelas kontrol 71,50. Berdasarkan analisis uji kesamaan dua rata-rata pada Tabel 31 didapatkan bahwa nilai sig $=0,000<$ 0,05 yang artinya bahwa terdapat perbedaan rata-rata kelas kontrol dan kelas perlakuan. Dimana pada kelas perlakuan yang menggunakan Buku Ajar Biologi berbasis Project Based Learning memiliki rata-rata nilai 81,17 lebih tinggi dibandingkan dengan ratarata nilai kelas kontrol yaitu 71,50.

Begitu juga dilihat dari rata-rata nilai kelas perlakuan mengalami peningkatan kreativitas 81,17 lebih tinggi dibandingkan kelas kontrol yang hanya 71,50. Hal ini menunjukkan bahwa penggunaan Buku Ajar Biologi berbasis Project Based Learning ternyata mampu meningkatkan kreativitas siswa lebih tinggi dibandingkan dengan tidak menggunakan Buku Ajar. Atau berdasarkan perolehan rata-rata jumlah skor kemampuan berpikir kreatif kelas perlakuan yang menggunakan Buku Ajar diperoleh nilai rata-rata 16,3 dengan kategori baik. Sedangkan kelas kontrol hanya memperoleh nilai ratarata 14,3 dengan kategori peningkatan sedang.

Dapat diketahui bahwa nilai $\mathrm{t}$ hitung sebesar 5,291 dengan signifikansi 0,000 . Nilai signifikan yang menunjukkan $0,000<0,05$ maka Ho ditolak. Hal ini juga didukung oleh nilai mean kelas perlakuan yaitu sebesar 78,4000 lebih besar dari kelas kontrol yaitu sebesar 69,5500. Dari pengujian di atas dapat disimpulkan 
bahwa ada pengaruh penggunaan Buku Ajar terhadap kreativitas belajar Biologi peserta didik kelas X IPA di SMAN 1 Penengahan semester genap tahun pelajaran 2016/2017.

Berdasarkan hasil analisis data dan pengujian hipotesis mengenai penggunaan Buku Ajar terhadap kreativitas belajar peserta didik kelas $\mathrm{X}$ IPA di SMAN 1 Penengahan didapat hasil penelitian bahwa ada perbedaan yang signifikan antara $t_{\text {hitung }}=5,29$ sedangkan $t_{\text {tabel }}=2,00$ pada taraf signifikansi 0,05 . Hal ini didukung oleh adanya rata-rata nilai kreativitas peserta didik dengan pembelajaran menggunakan Buku Ajar sebesar 78,40 lebih tinggi dibanding kelas kontrol sebesar 69,55 yang menggunakan pembelajaran konvensional. Sehingga dapat disimpulkan bahwa ada pengaruh signifikan penggunaan produk Buku Ajar.

\section{KESIMPULAN}

Berdasarkan hasil penelitian dan pengembangan Buku Ajar Biologi berbasis Project Based Learning, penulis dapat menyimpulkan beberapa hal, yaitu:

1. Buku Ajar disusun secara runtut dan sistematis, terbagi dalam tiga bagian yaitu pembukaan/pendahuluan, isi/batang tubuh dan penutup. Materi yang disajikan dapat memudahkan proses pembelajaran, menarik minat siswa, untuk lebih meningkatkan aktivitas belajar yang lebih interaktif dan lebih kritis sehingga dapat meningkatkan kreativitas siswa dalam menghadapi masalah-masalah materi yang dihadapi dan masalahmasalah lingkungan dalam kehidupan sehari-hari. Bahasa yang digunakan dalam Buku Ajar sederhana, lugas dan mudah difahami serta bersifat komunikatif. Bahasa yang digunakan sesuai EYD yang benar dengan menggunakan peristilahan yang sesuai dengan konsep kompetensi dasar.

2. Kelayakan Buku Ajar yang dikembangkan memenuhi kriteria 'sangat layak' dengan keterpakaian 'sangat baik'.

3. Ada perbedaan rata-rata hasil belajar dan kreativitas siswa pada kelompok kelas perlakuan yang menggunakan Buku Ajar dengan siswa pada kelompok kelas kontrol yang tidak menggunakan Buku Ajar. Buku Ajar yang dikembangkan menekankan aktivitas dan kemandirian siswa melalui pembelajaran berbasis proyek/PjBL. Dengan penggunaan Buku Ajar pada kelompok siswa kelas perlakuan diperoleh hasil peningkatan kreativitas siswa yang baik/tinggi, sedangkan pada kelompok siswa kelas kontrol diperoleh rata-rata kreativitas sedang. Buku Ajar terbukti membantu pencapaian ketuntasan kompetensi siswa disebabkan Buku Ajar mudah difahami terlihat dari respon siswa pada tingkat keterbacaan yang tergolong sangat baik.

\section{SARAN}

Berdasarkan hasil penelitian dan pengembangan yang penulis lakukan disampaikan saran-saran sebagai berikut:

1. Pembelajaran biologi hendaknya menggunakan model pembelajaran yang memberikan ruang untuk kebebasan dan aktivitas tinggi bagi siswa yang sejalan dengan kurikulum 2013. Oleh karena itu, guru biologi perlu merancang dan mengidentifikasi model-model pembelajaran yang dapat meningkatkan tidak hanya penguasaan konsep tetapi lebih pada peningkatan kreativitas siswa.

2. Peserta didik dapat menggunakan buku ajar berbasis PjBL sebagai 
bahan dan sumber belajar alternatif dalam meningkatkan penguasaan konsep dan peningkatan kreativitas nya.

3. Sekolah diharapkan dapat memberikan dukungan kepada guru dan siswa melalui pelatihan pembelajaran, menambah kelengkapan sarana prasarana pembelajaran,

menganekaragamkan bahan dan sumber belajar, dalam mendukung proses pembelajaran yang berkualitas dan pencapaian tujuan pembelajaran yang diperoleh siswa baik pengetahuan, ketrampilan, maupun sikap.

4. Pengembangan Buku Ajar berbasis Project Based Learning ini terbatas pada materi Limbah dan Daur Ulang Limbah dan peningkatan kreativitas siswa, untuk pengembangan lebih lanjut, perlu dilakukan pengembangan yang berfokus kepada peningkatan kreativitas siswa melalui berbagai model dan materi pembelajaran lainnya. Diadakan pelatihan pengembangan penyusunan buku ajar dengan berbagai model pembelajaran yang dapat meningkatkan kreativitas siswa pada materi pokok lainnya sesuai kompetensi dasar dalam

pelajaran biologi SMA di semua jenjang.

\section{DAFTAR PUSTAKA}

Astuti, R. 2015. Meningkatkan Kreativitas Siswa Dalam Pengolahan Limbah Menjadi Trash Fashion Melalui PjBL. Jurnal Bioedukasi, Volume 8, Nomor 2. Universitas Pendidikan Indonesia.
Daryanto dan A. Dwicahyono. 2014. Pengembangan Perangkat Pembelajaran (Silabus, RPP, PHB, Bahan Ajar. Yogyakarta: Penerbit Gava Media.

Hamalik. 2009. Proses Belajar mengajar. Jakarta: Bumi Aksara.

Hardini, I dan D. Puspitasari. 2012. Strategi Pembelajaran Terpadu (Teori, Konsep dan Implementasinya). Yogyakarta: Familia.

Karwono. 2007. Pemanfaatan Sumber Belajar dalam Upaya Peningkatan Kualitas dan Hasil Pembelajaran. Makalah disampaikan dalam Seminar tentang Pemanfaatan Sumber Belajar tanggal 13 November 2007 di Metro. . [Online]. Tersedia: https://karwono. wordpress.com/ 2007/11/09/seminar-sumberbelajar/. $\{4$ November 2016\}.

Mendikbud RI. 2016. Permendikbud Nomor 22 tanggal 6 Juni 2016.

Standar Proses Pendidikan Dasar dan Menengah. Jakarta: Dedikbud RI.

Prastowo, A. 2012. Panduan Kreatif Membuat Bahan Ajar Inovatif. Yogyakarta: Diva Pres.

Prastowo, A. 2015. Panduan Kreatif Membuat Bahan Ajar Inovatif. Yogyakarta: Diva Pres.

Talajan, G. 2012. Menumbuhkan kreativitas dan Prestasi Guru. Yogyakarta: Laksbang Presindo.

Trianto. 2011. Model Pembelajaran Terpadu. Jakarta: Bumi Aksara.

Warsono dan Hariyanto. 2012. Pembelajaran Aktif, Teori dan Asesmen. Bandung: PT. Remaja Rosdakarya Offset. 